\title{
Politisk forvaltning og politisk forvaltningsforskning
}

Jørgen Grønnegaard Christensen og Peter Bjerre Mortensen, 2016

I politikkens vold: Offentlige lederes vilkår og muligheder

Jurist- og Økonomforbundets Forlag, København

243 sider, $285 \mathrm{kr}$.

Anmeldt af Tim Knudsen, professor emeritus ved Institut for Statskundskab, Københavns Universitet

Denne lærebog i forvaltning i et politologisk perspektiv er skrevet med især driftsledere i den offentlige forvaltning som målgruppe. Udgangspunktet er, at offentlige ledere på den ene side opererer $i$ et demokratisk samfund, hvor politikerstyringen sætter rammer for deres virksomhed. På den anden side er denne styring ofte upræcis samt præget af uklare mål og uklare koblinger mellem reformer, ledelse og effektivitet. Bogen opererer med tre effektivitetsbegreber: Omkostningseffektivitet, resultateffektivitet og allokeringseffektivitet. Henvisninger til effektivitet anvendes ofte som argumenter for det ene eller andet, men politik trumfer i praksis ofte effektivitet og især omkostningseffektivitet i det offentlige, siger bogen. Forfatterne understreger, at heller ikke private virksomheder altid lever op til forventningerne om, at de er den offentlige forvaltning indiskutabelt overlegen. Det fastlås, at formodninger om private virksomheders generelle overlegenhed langt fra er underbygget af empirisk forskning.

Den bærende teoretiske opfattelse i bogen er, at individer har begrænset, men tilstræbt rationalitet. Et fortrin ved bogen er, at den gennemgår væsentlige dele af udviklingen i beslutningsteori. Det kunne have været udvidet til en hel bog. Men bogen underspiller, at rationalitet ved offentlige beslutninger ikke kun er et spørgsmål om individer, det er også et spørgsmål om et organiseret samspil mellem flere personer og institutioner. Det samspil kan både præges af ansvarsløshed og forvridende magtforhold, som forstærker risikoen for fejlvurderinger, men det kan jo også dæmpe individuelle idiosynkrasier og blind spots. 


\section{Manøvrerum og møgsager}

Dele af den nyere forvaltningsforskning ser offentlige organisationsformer mere som et spørgsmål om magt end som udtryk for en samlet systemrationalitet. Den opfattelse er forudsat i bogen. Men det skal vel ikke forhindre, at 'tilstræbt rationelle' offentlige ledere lærer mere organisationsteori, end tilfældet er i denne bog?

Men forfatterne vil helst hurtigt frem til, at den begrænsede rationalitet giver driftslederen i det offentlige manøvremuligheder. At udnytte dem kræver, at lederen forstår at læse den (politiske) virkelighed, hun opererer i. Hensigten med bogen er at træne lederen $i$ at læse politik for at sejle sin organisation/institution sikkert gennem den omskiftelige politiske virkelighed. Måske burde bogen også lægge mere vægt på at træne lederen $i$ under denne sejlads at bruge andres viden og erfaringer.

I det offentlige kan der jo ifølge bogen opstå, hvad bogen kalder møgsager. Det kaldes af andre for skandalesager (potentielle eller evidente). Det er på grund af møgsagerne også et af formålene med bogen at skærpe ledernes blik for det tætte samspil mellem ledelse, forvaltning og politik. Teorien om begrænset rationalitet forklarer, at man i den offentlige forvaltning typisk fokuserer på løsninger, der er gode nok (satisfierende) frem for optimale løsninger. Kimen til en møgsag ligger i, at det ikke er klart nok formuleret oppefra, hvad der er godt nok, ligesom vurderingen af, hvad der er godt nok, kan skifte over tid med tilbagevirkende kraft. Kimen til en møgsag ligger også i den begrænsede rationalitet (det kunne være hos skiftende ledere, der er generalister uden at have specifik faglighed på deres område).

I bogen forsøges disse pointer om møgsager illustreret med cases fra den danske virkelighed. Men her forekommer det mig, at bogen i nogle tilfælde løber ind i, at det kan være svært at dissekere en møgsag. Nogle sager er meget komplekse, og analysen af dem kan være kontroversiel. Bogen forsøger at løse problemet ved at referere til undersøgelseskommissioner, ombudsmanden eller Rigsrevisionen. Disse institutioner repræsenterer selvsagt vigtige kontrolorganer og har muligheder for at komme tæt på møgsager. Men er det altid tæt nok?

Tegn på manglende respekt for eksempelvis ombudsmanden er ikke umulige at opdrive. Politikere som Inger Støjberg og Martin Henriksen er blandt eksemplerne på dette. Er ombudsmandens autoritet vigende med det resultat, at hans undersøgelser $\mathrm{i}$ nogle tilfælde ikke når ret dybt? Og i eksempelvis statsløsesagen gengiver bogen uddrag af embedsfolks forklaringer til undersøgelseskommissionen, som var de afhørtes udsagn endelige sandheder. Men det kan jo være, at de afhørte i al fald har været så rationelle, at de først og fremmest havde for øje at undgå at sidde tilbage med aben. Det er heller ikke utænkeligt, at de har forsøgt at undgå at lægge sig ud med deres overordnede. Noget af det vanskelige for såvel undersøgelseskommissioner som den empiriske forvaltningsforskning er at opfange, hvordan de politiske forventninger osmotisk siver ned i forvaltningen. I det hele taget er bogen en illustration af, at skønt den politologiske forvaltningsforskning er nået langt, så er det ofte vanskeligt at konkludere uden betydelig usikkerhed. 


\section{Politik, forvaltning og politisk forvaltningsforskning}

Bogen kan læses som et mere samlet overblik over seniorforfatteren Jørgen Grønnegård Christensen opfattelser. Grønnegårds nærmest frygtindgydende flid har været med til at give ham en helt dominerende rolle i dansk politologisk forvaltningsforskning og ikke mindst som repræsentant for denne forskning i officielle sammenhænge. De akademiske dyder og laurbær har betydet mindre for ham.

Han har i stedet udtrykt sig i utallige avisartikler, artikler og bøger. Ofte med ingen eller få referencer. Den røde tråd hos Grønnegård har dog været, at det ikke er muligt at adskille politik og forvaltning. Det var Grønnegård ikke den første til at sige. Heller ikke i Danmark, hvor Lennart Lundquist, der var den første politologiske forvaltningsprofessor, på hvad der i dag kaldes Institut for Statskundskab i København, kom før Grønnegård. Men Lundquist valgte ikke som Grønnegård at gå i tæt samspil med forvaltningens topfolk. Blandt andet fordi Lundquist vel ønskede, at forvaltningsforskningen ikke skulle risikere at blive spændt for en snæver politiserende vogn. Grønnegård har derimod medvirket ved talrige betænkninger og har arbejdet for blandt andet ministerierne.

Selv om Grønnegård nok aldrig helt har fremlagt sine forskningsmæssige udgangspunkter systematisk, så har forvaltningens politiske responsivitet vel altid stået $\mathrm{i}$ centrum. Det er nok også fair at sige, at det samme har effektivitet i enhver forstand af begrebet. Målgruppen har især været nuværende eller kommende ledere i det offentlige i form af statskundskabsstuderende De retlige, saglige, faglige og etiske grænser for forvaltningen har ikke haft samme bevågenhed som hos Lundquist, som måske af samme grund nok ikke har haft samme indflydelse på embedsfolk som Grønnegård. Budskabet om jura i denne bog er, at den langt fra er entydig. Det er korrekt, men man skal ikke se bort fra, at der dog er tilfælde, hvor gældende lovgivning overtrædes så flagrant, at ingen kan være i tvivl. Bogen nævner selv statsløsesagen som eksempel herpå. Det er heller ikke svært at finde sager, hvor ansvaret tilsyneladende forsvinder i den blå luft. Eller hvor den faglige kvalitet er diskutabel. For øjeblikket ligner skatteskandalerne og hjemsendelserne af somaliske flygtninge eksempler herpå. Se i øvrigt om skandalesager blandt andet i Pernille Boye Koch og Tim Knudsen: Ansvaret der forsvandt (udgivet på Samfundslitteratur, 2014) som uden nærmere kritik affejes i bogen som jamren over tidernes fordærv. Argumentation er nu ellers en god akademisk dyd. Heller ikke bogens reformdebat har Grønnegård ofret tid på. Det ville vel heller ikke skade forvaltningspolitologien, hvis den kunne assimilere noget forvaltningsret.

I bogen giver Grønnegård sammen med sin yngre kollega, Peter Bjerre Mortensen, et mere systematisk billede af sin læsning af forvaltningslitteraturen. Men bogen viser også klart, at forvaltningspolitologien ikke giver firkantede opskrifter til en håndbog, der kan vejlede en driftsleder i komplekse situationer. Forklaringen kan blandt andet være, at det er ganske svært at komme til at studere forvaltning empirisk, uden at det bliver mere eller mindre på forvaltningsledelsens betingelser. Dermed er det også mere eller mindre sagt, at bogen kan give anledning til hjernegymnastik og eftertanke, 
men at andre discipliner som forvaltningsret, forvaltningshistorie, demokratiteori, organisationsteori og mikroøkonomi ikke er at foragte.

Den nyligt udkomne bog af Peter Loft og Jørgen Rosted om, hvordan departementschefrollen er sprængt af alt for store krav, understreger jo den begrænsede rationalitet, de begrænsede kompetencer og de begrænsede kræfter også hos departementschefer (Loft og Rosted: Hvem har ansvaret? udgivet på Gyldendal Public, 2016). Grønnegård kunne dårligt anmelde den med andet end respekt for de to departementschefers praktiske erfaringer. Det er også forståeligt, at han til gengæld fandt de to forfatteres forslag til forbedringer utilstrækkelige. Så dem affejede han (Weekendavisen 02.09.2016). Men Grønnegårds affejning løser ikke problemerne. Hvor ville det være rart, hvis forfatterne selv vovede sig ud i overvejelser om reformer. Uanset hvad der er politisk opportunt. Og med flere hensyn end nærværende bog tager. 